\title{
PENGARUH KEPERCAYAAN DAN HARGA TERHADAP KEPUTUSAN PEMBELIAN ONLINE MELALUI MEDIA SOSIAL INSTRAGRAM PADA MAHASISWA STIE RAHMANIYAH
}

\author{
Oleh: \\ Usailan Oemar \\ Sekolah Tinggi Ilmu Ekonomi Rahmaniyah \\ Email: usailanoemar7@gmail.com \\ Ropal Tores \\ Sekolah Tinggi Ilmu Ekonomi Rahmaniyah \\ Email: toresropal@gmail.com_
}

\begin{abstract}
ABSTRAK
Penelitian ini menggunakan variabel bebas $(\mathrm{X})$ dan vaiabel bebas $(\mathrm{Y})$ didapatkan hasil yaitu: faktor kepercayaan $\left(\mathrm{X}_{1}\right)$, tidak berpengaruh secara parsial terhadap keputusan pembelian secara online karena memiliki nilai $t$ hitung $<\mathrm{t}$ tabel. Juga faktor harga $\left(\mathrm{X}_{2}\right)$ tidak berpengaruh secara parsial terhadap keputusan pembelian secara online karena mempunyai nilai $t$ hitung $<\mathrm{t}$ tabel. Begitu pula secara simultan atau bersama-sama kercayaan $\left(\mathrm{X}_{1}\right)$ dan faktor harga $\left(\mathrm{X}_{2}\right)$, tidak berpengaruh terhadap keputusan pembelian secara online melalui media sosial instragram (Y) mahasiswa program studi S1 manajemen STIE Rahmaniyah Sekayu. Hal ini dibuktikan dari nilai $\mathrm{f}_{\text {hitung }}$ sebesar 3,288 $<\mathrm{f}_{\text {tabel }} 3,88$. Sesuai dengan rentang interprestasi koefisien korelasi maka dapat dinyatakan bahwa kepercayaan $\left(\mathrm{X}_{1}\right)$, dan harga $\left(\mathrm{X}_{2}\right)$, memiliki hubungan yang sangatt rendah terhadap keputusan pembelian online melalui media sosial instragram (Y) mahasiswa program studi S1STIE Rahmaniyah Sekayu dibuktikan dari nilai korelasi ganda sebesar 0.165.

Kata kunci: fakor kepercayaan, faktor harga, dan keputusan pembelian online melalui media sosial instragram.
\end{abstract}

\section{Latar Belakang}

Seiring dengan kemajuan teknologi, saat ini internet tidak hanya digunakan sebagai alat komunikasi namun juga digunakan sebagai media jual beli. Jual beli melalui internet biasanya disebut dengan online shop. Semakin meningkatnya pengguna internet membuat para pelaku bisnis juga memanfaatkan media internet sebagai salah satu tempat untuk memasarkan produknya. Perkembangan teknologi internet juga telah mengubah berbagai aspek kehidupan termasuk perilaku konsumen.

Internet merupakan salah satu kebutuhan yang tidak dapat dipisahkan dari kehidupan masyarakat saat ini. Penetrasi pengguna internet di Indonesia menunjukkan semakin banyak masyarakat yang sudah melek teknologi khususnya internet. Pada tahun 2017 pengguna internet di Indonesia sebanyak 143,26 juta jiwa. Sedangkan pada tahun 2018 angka penetrasi pengguna internet di Indonesia adalah 54,68 persen atau sekitar 152,24 juta jiwa dari total populasi penduduk Indonesia sebesar 262 juta jiwa, terjadi peningkatan jumlah pengguna internet sebesar 10,56 juta jiwa. Jumlah yang sangat berpotensi untuk bertambah di masa yang akan datang.(Asosiasi Penyelenggara Jasa Internet Indonesia, APJII 2018)

Aktivitas pengguna internet di Indonesia yang terbilang cukup tinggi akan membuka kesempatan masyarakat Indonesia untuk melakukan belanja online. Masyarakat Indonesia dengan persentase sebesar 26.48 persen menghabiskan waktu diatas tujuh jam untuk mengakses internet setiap harinya dan sebesar 29,63 persen masyarakat mengakses internet sebanyak empat sampai tujuh jam dan 43,89 persen masyarakat mengakses internet sebanyak satu sampai tiga jam (APJII 2018). Selain itu juga mayoritas pengguna internet didominasi kalangan muda dalam rentang usia 13 sampai 18 tahun dengan 75,50 persen, usia 19 sampai 34 tahun dengan 74,23 persen dan usia 35 sampai 54 tahun dengan 44,06 persen (APJII 2018).

Salah satu media sosial yang saat ini banyak diminati untuk belanja online adalah Instagram. Instagram adalah sebuah aplikasi berbagi foto yang memungkinkan pengguna mengambil foto, menerapkan filter digital, dan membagikannya keberbagai layanan jejaring sosial. Kini telah banyak 
akun-akun Instagram yang dipakai untuk berjualan dan barang-barang yang di jual di Instagram sangat beragam (Suwakdi, 2016: 123).

Sejak pesatnya perkembangan berbagai media sosial seperti Facebook, Twitter, Instagram dll.Instagram menjadi jejaring sosial besar dengan pertumbuhan paling pesat di 2014. Bedanya Instagram dengan Twitter, Instagram saat ini dianggap sebagian orang lebih nyaman karena foto produk yang diunggah langsung bisa dilihat sedangkan Twitter hanya menonjolkan pesan teks atau yang disebut Caption. Bedanya Instagram dengan Facebook, pada Instagram kita bisa mengetahui seberapa banyak followers toko tersebut. Semakin banyak followers akan membuktikan bahwa toko tersebut aman sedangkan pada Facebook hanya menampilkan Foto dan Caption produk. Pembeli tidak bisa mengetahui berapa banyak followers-nya, apakah aman dan banyak yang membeli di toko tersebut..

Menurut Mowen dan Minor dalam Widyawati (2008: 74-96), menjelaskan bahwa kepercayaan konsumen adalah semua pengetahuan yang dimiliki oleh konsumen dan semua kesimpulan yang dibuat konsumen tentang objek, atribut dan manfaatnya. Objek dapat berupa produk, orang, perusahaan dan segala sesuatu dimana seseorang memiliki kepercayaan dan sikap. Atribut adalah karakteristik atau fitur yang mungkin dimiliki atau tidak dimiliki oleh oleh objek. Sedangkan manfaat adalah hasil positif yang diberikan kepada konsumen. Kepercayaan secara umum dipandang sebagai unsur mendasar bagi keberhasilan relationship. Tanpa adanya kepercayaan, suatu relationship tidak akan bertahan dalam jangka waktu yang panjang.

Menurut Hasanah (2017: 6) Selain kepercayaan, harga merupakan faktor yang mempengaruhi dalam keputusan konsumen, Konsumen mengharapkan harga dalam toko online lebih rendah daripada toko offline (tradisional) sehingga konsumen mencari tahu perbandingan harga produk offline dan produk online. Harga jual yang berbeda antara penjual satu dengan penjual yang lain serta pelayanan yang diberikan juga menjadi faktor dalam keputusan pembelian online. Pada umumnya, harga yang terjangkau dan relatif lebih murah disertai biaya pengiriman juga murah, dapat menarik konsumen untuk melakukan pembelian melalui online shop.

Menurut Kotler dan Keller (2016: 201) pengambilan keputusan konsumen adalah proses merasa dan mengevaluasi informasi merek, mempertimbangkan bagaimana alternatif merek memenuhi kebutuhan konsumen dan memutuskan pada suatu merek. Pengambilan keputusan membeli merupakan keputusan konsumen tentang apa yang hendak dibeli, berapa banyak yang akan dibeli, di mana akan dilakukan, kapan akan dilakukan dan bagaimana pembelian akan dilakukan.

Proses keputusan pembelian selalu terjadi pada konsumen saat akan membeli suatu produk. Salah satu produk yang banyak diminati oleh konsumen terutama pada kalangan remaja dan mahasiswa adalah produk pakaian atau fashion pembelian melalui e-commerce yang dipublikasikan oleh Kementrian Komunikasi dan Informatika RI (KEMKOMINFO) menggambarkan bahwa produk yang paling banyak dibeli secara online dalam tahun 2018 adalah produk fashion $(73,80 \%)$.

Dari hasil penelitian sementara penulis pengguna Handphone dan media sosial pada Mahasiswa Program Studi S1 STIE Rahmaniyah Sekayu semakin meningkat dan berkembang sehingga mahasiswa yang menggunakan Instagram juga meningkat pada setiap tahunnya, sampai akhir tahun 2018 ada 90 mahasiswa yang menggunakan Instragram.

Berdasarkan uraian latar belakang masalah di atas maka peneliti tertarik untuk mengadakan penelitian dengan judul "Pengaruh Kepercayaan Dan Harga Terhadap Keputusan Pembelian Online Melalui Media Sosial Instragram Pada Mahasiswa Program Studi S 1 Stie Rahmaniyah Sekayu".

Berdasarkan uraian latar belakang yang telah dikemukakan di atas maka perumusan masalah adalah:

1. Bagaimana pengaruh kepercayaan dan harga secara simultan terhadap keputusan pembelian online melalui media sosial Instagram (pada Mahasiswa Program Studi S1 STIE Rahmaniyah Sekayu)?

2. Bagaimanapengaruh kepercayaan dan harga secara parsial terhadap keputusan pembelian online melalui media sosial Instagram (pada Mahasiswa Program Studi S1 STIE Rahmaniyah Sekayu)?

Adapun Tujuan yang akan dicapai dalam penelitian ini adalah: 
1. Untuk mengetahui bagaimana pengaruh kepercayaan dan harga secara simultan terhadap keputusan pembelian online melalui media sosial Instagram (pada mahasiswa Program Studi S1 STIE Rahmaniyah Sekayu).

2. Untuk mengetahui pengaruh kepercayaan dan harga secara parsial terhadap keputusan pembelian online melalui media sosial Instagram (pada mahasiswa Program Studi S1 STIE Rahmaniyah Sekayu).

\section{Kajian Pustaka}

\section{Kepercayaan Konsumen}

Menurut Sumarwan (2011: 165-166), kepercayaan konsumen adalah pengetahuan konsumen mengenai suatu objek, atributnya, dan manfaatnya. Berdasarkan konsep tersebut, maka pengetahuan konsumen sangat terkait dengan pembahasan sikap karena pengetahuan konsumen adalah kepercayaan konsumen. Kepercayaan konsumen atau pengetahuan konsumen menyangkut kepercayaan bahwa suatu produk memiliki berbagai atribut, dan manfaat dari berbagai atribut tersebut.

\section{Indikator Kepercayaan}

Kepercayaan didefinisikan sebagai keinginan untuk menggantungkan diri pada mitra bertukar yang dipercayai. Greenyang dalam Fasochah dan Hartono (2013: 19), menyatakan bahwa komponenkomponen kepercayaan adalah:

1. Kredibilitas

Kredibilitas berarti bahwa karyawan jujur dan kata-katanya dapat dipercaya. Kredibilitas harus dilakukan dengan kata-kata, "saya dapat mempercayai apa yang dikatakannya mengenai" bentuk lain yang berhubungan adalah believability dan truthfulness.

2. Reliabilitas

Reliabilitas berarti sesuatu yang bersifat reliable atau dapat dihandalkan. Ini bearti berhubungan dengan kualitas individu/organisasi. Reliabilitas harus dilakukan dengan tindakan, "saya dapat memercayai apa yang akan dilakukannya". Bentuk lain yang berhubungan adalah predictability dan familiarity.

3. Integritas

Integritas berarti karyawan memiliki kualitas sebagai karyawan yang memiliki prinsip moral yang kuat. Integritas menunjukkan adanya internal consistency, ada kesesuaian antara apa yang dikatakan dan dilakukan, ada konsistensi antara pikiran dan tindakan. Selain itu integritas menunjukkan adanya ketulusan.

\section{Harga}

\section{Pengertian Harga}

Harga merupakan salah satu elemen bauran pemasaran yang menghasilkan pendapatan, sedangkan elemen lainnya menghasilkan biaya. Harga juga mengkomunikasikan positioning nilai yang dimaksudkan dari produk atau merek perusahaan pasar. Produk yang direncanakan dan dipasarkan dengan baik dapat dijual dengan harga tinggi dan menghasilkan laba besar. Dalam menetapkan harga diperlukan suatu pendekatan yang sistematis, yang melibatkan penetepan tujuan dan mengembangkan suatu struktur penetapan harga yang tepat.

Sedangkan menurut Buchari Alma (2011: 169) harga sebagai nilai suatu barang yang dinyatakan dengan uang.harga memiliki dua peranan utama dalam proses pengambilan keputusan para pembeli, yaitu peranan alokasi dan peranan informasi. Selanjutnya pengertian harga menurut Daryanto (2013: 62) mendefinisikan harga sebagai jumlah uang yang ditagihkan untuk suatu produk atau sejumlah nilai yang dipertukarkan konsumen untuk manfaat memiliki atau menggunakan produk.

Berdasarkan definisi-definisi diatas maka dapat disimpulkan bahwa harga adalah sejumlah nilai yang ditukarkan oleh konsumen untuk memperoleh suatu manfaat atas barang atau jasa baik yang bisa dimiliki maupun digunakan fungsinya karena dimata konsumen harga merupakan atribut penting yang dievaluasi yang merangkap dengan nilai sosial non keuangan yang harus dikorbankan dan bagi perusahaan peran harga dapat membentuk sikap konsumen.

\section{Indikator Harga}


Menurut Kotler dan Amstrong (2012: 52), didalam variabel harga ada beberapa unsur kegiatan utama harga yang meliputi daftar harga, diskon, potongan harga, dan periode pembayaran. Menurut Kotler dan Amstrong (2012: 278), ada empat indikator yang mencirikan harga yaitu :

1. Keterjangkauan harga

2. Kesesuaian harga dengan kualitas produk

3. Daya saing harga

4. Kesesuaian harga dengan manfaat

\section{Keputusan Pembelian}

\section{Pengertian Keputusan Pembelian}

Menurut Kotler dan Armstrong (2012: 190), keputusan pembelian adalah tahap dalam proses pengambilan keputusan pembeli di mana konsumen benar-benar membeli. Pengambilan keputusan merupakan suatu kegiatan individu yang secara langsung terlibat dalam mendapatkan dan mempergunakan barang yang ditawarkan. Konsumen dapat membentuk niat untuk membeli merek yang paling disukai. Keputusan pembelian merupakan suatu proses pengambilan keputusan akan pembelian yang mencakup penentuan apa yang akan dibeli atau tidak melakukan pembelian.

Kotler dan Armstrong (2012: 196) juga berpendapat, bahwa keputusan untuk membeli yang diambil oleh pembeli sebenarnya merupakan kumpulan dari sejumlah keputusan. Setiap keputusan untuk membeli tersebut mempunyai suatu struktur sebanyak tujuh komponen, yang meliputi:

1. Keputusan tentang jenis produk

Dalam hal ini konsumen dapat mengambil keputusan tentang produk apa yang akan dibelinya untuk memenuhi dan memuaskan kebutuhan.

2. Keputusan tentang bentuk produk

Konsumen dapat mengambil keputusan untuk membeli suatu produk dengan bentuk tertentu sesuai dengan seleranya.

3. Keputusan tentang merek

Konsumen harus mengambil keputusan tentang merek mana yang akan dibeli karena setiap merek mempunyai perbedaan-perbedaan tersendiri.

4. Keputusan tentang penjualnya

Konsumen dapat mengambil keputusan dimana produk yang dibutuhkan tersebut akan dibeli.

5. Keputusan tentang jumlah produk

Konsumen dapat mengambil keputusan tentang seberapa banyak produk yang akan dibeli.

6. Keputusan tentang waktu pembelian

Konsumen dapat mengambil keputusan tentang kapan dia harus melakukan pembelian.

7. Keputusan tentang cara pembayaran

Konsumen dapat mengambil keputusan tentang metode atau cara pembelian produk yang akan dibeli, apakah secara tunai atau kredit. Keputusan tersebut akan mempengaruhi keputusan tentang penjualan dan jumlah pembeliannya.

Kotler dan Keller (2016: 195) menyatakan bahwa proses keputusan pembelian terdiri dari lima tahap sebagai berikut.

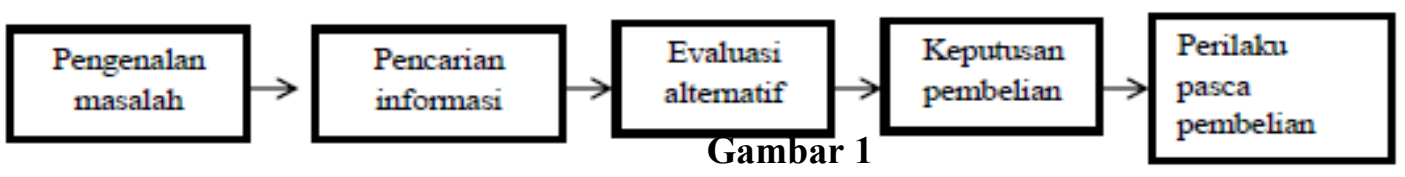

Proses Keputusan Pembelian

1. Problem recognition (Pengenalan Masalah)

Proses pembelian dimulai saat pembeli mengenali masalah atau perlu dipicu oleh rangsangan internal atau eksternal. Dengan satu stimulus internal kebutuhan normal seseorang.

2. Information search (Pencarian Informasi)

Konsumen tertarik mungkin atau mungkin tidak mencari informasi lebih lanjut. Jika drive konsumen kuat dan produk yang memuaskan sudah dekat, ia mungkin membelinya kemudian. Jika tidak, konsumen dapat menyimpan kebutuhan dalam memori atau melakukan pencarian informasi yang terkait dengan kebutuhan.

3. Evalution of alternatives (Evaluasi Alternatif) 
Evaluasi alternatif itu adalah bagaimana konsumen memproses informasi untuk sampai pada pilihan merek.

4. Purchase decision (Keputusan Pembelian)

Umumnya, keputusan pembelian konsumen akan membeli merek yang paling disukai, tapi dua faktor bisa datang antara niat beli dan keputusan pembelian.

5. Postpurchase behavior (Perilaku Pasca Pembelian)

Setelah pembelian, konsumen mungkin mengalami disonansi dari melihat fitur menggelisahkan tertentu atau mendengar hal-hal baik tentang merek lain dan akan waspada terhadap informasi yang mendukung keputusannya.

\section{Penelitian Terdahulu}

Penelitian terdahulu merupakan acuan bagi penulis untuk membandingkan hasil penelitiannya dengan penelitian yang telah dilakukan oleh penulis terdahulu. Adapun penelitian terdahulu yang menjadi landasan penulis untuk melakukan penelitian ini, sebagai berikut :

Kony Fransiska (2018), Analisa Pengaruh Harga, Desain dan Celebrity Endorser Terhadap Keputusan Pembelian Produk Pakaian (Studi Kasus pada Konsumen R.A. Jeans di Media Sosial Instagram. Program Studi Manajemen Fakultas Ekonomi Universitas Sanata Dharma. Hasil penelitian menunjukkan bahwa terdapat pengaruh yang signifikan antara harga, desain dan celebrity endorser terhadap volume keputusan pembelian produk pakaian R.A Jeans.

Suny (2017). Pengaruh Kepercayaan, Kemudahan dan Kualitas Informasi Penjualan Terhadap Keputusan Pembelian Secara Online oleh Mahasiswa Politeknik Negeri Batam. Program Akuntansi Manajerial Jurusan Manajemen Bisnis Politeknik Negeri Batam. Hasil penelitian menunjukkan bahwa: Tingkat kepercayaan tidak berpengaruh terhadap keptusan pembelian online. Tingkat kemudahan tidak berpengaruh terhadap keputusan pembelian online. Tingkat kualitas informasi berpengaruh terhadap keputusan pembelian online

Anis Pusposari (2017). Pengaruh Kualitas Layanan, Kepercayaan, dan Harga Terhadap Keputusan Pembelian Online Produk Busana Melalui Media Sosial Instagram di Kalangan Mahasiswa Fakultas Ekonomi dan BisnisIslam IAIN Surakarta. Jurusan Manajemen Binis Syariah Fakultas Ekonomi dan Bisnis Islam IAIN Surakarta. Hasil penelitian menunjukkan bahwa: Faktor Kualitas layanan berpengaruh terhadap keptusan pembelian online. Faktor kepercayaam berpengaruh terhadap keptusan pembelian online Faktor harga tidak berpengaruh terhadap keptusan pembelian online

\section{Kerangka Pemikiran}

Sebagai acuan dalam penulisan penelitian ini penulis merumuskan kerangka pemikiran sebagai berikut :

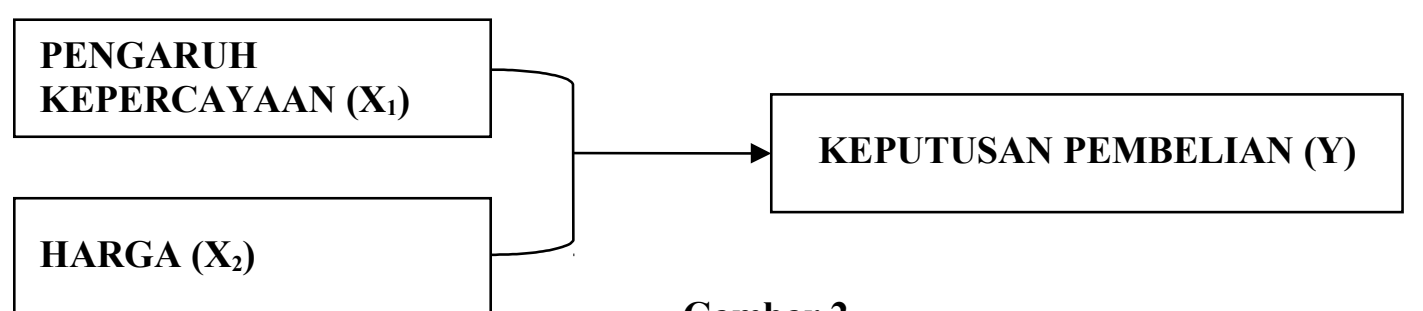

Gambar 2

Kerangka Pemikiran

\section{Hipotesis}

Menurut Sugiyono (2017: 99-102), hipotesis merupakan jawaban sementara terhadap rumusan masalah penelitian, di mana rumusan masalah penelitian telah dinyatakan dalam bentuk kalimat pertanyaan. Jadi hipotesis juga dapat dinyatakan sebagai jawaban teoritis terhadap rumusan masalah penelitian, belum jawaban yang empirik. Adapun hipotesis dalam penelitian ini adalah: "Adanya pengaruh kepercayaan dan harga secara simultan maupun parsial terhadap keputusan pembelian online melalui media sosial Instagram (pada mahasiswa Program Studi S1 STIE Rahmaniyah Sekayu)".

\section{Metode Penelitian}

Variabel Penelitian

Menurut Sugiyono (2012: 145), variabel penelitian adalah hal yang terbentuk apa saja yang ditetapkan oleh peneliti untuk dipelajari sehingga diperoleh informasi tentang hal tersebut. 
Ada 2 (dua) variabel utama yang menjadi fokus perhatian penelitian ini yaitu variabel kepercayaan $\left(\mathrm{X}_{1}\right)$ dan variable harga $\left(\mathrm{X}_{2}\right)$ yang merupakan variabel independen, sedangkan variabel keputusan pembelian (Y) merupakan variabel dependen.

Definisi Operasional

\section{Faktor Kepercayaan $\left(\mathrm{X}_{1}\right)$}

Didefinisikan sebagai keinginan untuk menggantungkan diri pada mitra bertukar yang dipercayai. Green yang dikutip oleh Fasochah dan Hartono (2013: 19). Indikator yang dipergunakan kredibilitas, reliabilitas dan integritas.

\section{Fakto Harga $\left(\mathrm{X}_{2}\right)$}

Harga adalah sejumlah uang yang dibebankan atas suatu barang atau jasa atau jumlah dari nilai uang yang ditukar konsumen atas manfaat-manfaat karena memiliki atau menggunakan produk atau jasa tersebut. Kotler dan Armstrong (2013:151), Indikator yang dipergunakan keterjangkauan harga, kesesuaian harga dengan kualitas produk, daya saing harga, kesesuaian harga dengan manfaat.

3. Faktor Keputusan Pembelian (Y)

Sebuah proses dimana konsumen mengenal masalahnya, mencari informasi mengenai produk atau merek tertentu dan mengevaluasi seberapa baik masing-masing alternatif tersebut dapat memecahkan masalahnya yang kemudian mengarah kepada keputusan pembelian.Kotler dan Keller (2016: 195). Indikator yang dipergunakan pengenalan masalah, pencarian infomasi, evaluasi, alternative keputusan pembelian, perilaku pasca pembelian.

\section{Populasi dan Sampel}

Menurut Sugiyono (2012: 80), populasi adalah wilayah generalisasi yang terdiri dari objek atau subjek yang mempunyai kuantitas dan karakteristik tertentu yang ditetapkan oleh peneliti untuk dipelajari dan kemudian ditarik kesimpulan. Populasi dari penelitian ini adalah seluruh mahasiswa Program Studi S1 STIE Rahmaniyah Sekayu yang berjumlah 600 mahasiswa hingga 2018.yaitu, 400 manajemen dan 200 akuntansi.

Menurut Sugiyono (2012: 81) sampel adalah sebagian dari jumlah dan karakteristik yang dimiliki oleh populasi tersebut. Sampel digunakan sebagai ukuran sampel dimana ukuran sampel merupakan suatu langkah untuk mengetahui besarnya sampel yang akan diambil dalam melaksanakan suatu penelitian. Kemudian besarnya sampel tersebut biasanya diukur secara statiska ataupun estimasi penelitan. Untuk itu penulis menggunakan rumus Slovin dalam menentukan sampel, didapat 240 responden

\section{Teknik Pengumpulan Data}

Teknik pengumpulan data dalam penulisan ini yaitu kuesioner atau Angket (Questionairre). Menurut Sugiyono (2012:145) kuesioner merupakan teknik pengumpulan data yang dilakukan dengan cara memberi seperangkat pertanyaan atau pernyataan tertulis kepada para responden untuk dijawab.

\section{Teknik Analisis Data}

\section{Analisis Regresi Berganda}

Menurut Abdurahman (2011: 81) regresi linier berganda digunakan untuk bentuk hubungan antara dua variabel atau lebih, terutama untuk mengetahui sejauh mana hubungan antara variabel motivasi belajar dengan variabel independent (SERVIQUAL) digunakan analisis regresi berganda yaitu sebagai berikut:

$$
\mathrm{Y}=\mathrm{a}+\mathrm{bX}_{1}+\mathrm{bX} 2+e
$$

\section{Analisis Korelasi $\left(\mathbf{R}^{2}\right)$ Berganda}

Analisis korelasi berganda digunakan untuk mengetahui hubungan antara dua atau lebih variabel independen $\left(\mathrm{X}_{1}, \mathrm{X}_{2}, \ldots, \mathrm{X}_{\mathrm{n}}\right)$ terhadap variabel dependen $(\mathrm{Y})$ secara serentak. Koefisien ini menunjukan seberapa berhubungan yang terjadi antara variabel independent $\left(\mathrm{X}_{1}, \mathrm{X}_{2}, \ldots, \mathrm{X}_{\mathrm{n}}\right)$ terhadap variabel dependen $(\mathrm{Y})$. nilai $\mathrm{R}$ berkisar antara 0 sampai 1 , nilai semakin menddekati 1 berati hubungan yang terjadi semakin kuat, sebaliknya nilai semakin mendekati 0 maka hubungan yang terjadi semakin lemah. Analisis korelasi ganda dapat dihitung dengan rumus sebagai berikut:

$$
r y \cdot X_{1} X_{2}=\frac{\left(r y X_{1}\right)^{2}+\left(1 r y X_{2}\right)^{2}-2\left(r y X_{1}\right) \cdot\left(r y X_{2}\right) \cdot\left(r X_{1} \cdot X_{2}\right)}{1-\left(r X_{1} \cdot X_{2}\right)^{2}}
$$




\section{Pengujian Hipotesis}

Uji t (Secara Parsial)

Sanusi (2011:145) digunakan untuk mengetahui apakah masing-masing variabel bebasnya secara sendiri-sendiri berpengaruh secara signifikan terhadap varibel terikat dimana jika sig $>\alpha$ $(0,05)$, maka Ho diterima dan $\mathrm{H}_{1}$ ditolak dan sebaliknya jika sig $<\alpha(0,05)$ maka Ho ditolak dan $\mathrm{H}_{1}$ diterima. Penerimaan atau penolakan Ho dapat dilihat dari nilai probabilitas (sig $\mathrm{F}$ ) dimana jika sig $<\alpha$ maka Ho ditolak dan $\mathrm{H}_{\mathrm{a}}$ diterima dan jika Sig $>\alpha$ maka Ho diterima dan $\mathrm{H}_{\mathrm{a}}$ ditolak.

\section{Uji F (Secara Simultan)}

Sanusi (2011:165) menjelaskan bahwa uji F berfungsi untuk mengetahui signifikasi pengaruh/ hubungan antara semua varibel bebas dan variabel terikat. Penerimaan atau penolakan Ho dapat dilihat dari nilai probabilitas (sig F) dimana jika sig $<\alpha$ maka Ho ditolak dan $\mathrm{H}_{\mathrm{a}}$ diterima dan jika Sig $>\alpha$ maka Ho diterima dan $\mathrm{H}_{\mathrm{a}}$ ditolak.

\section{Hasil Dan Pembahasan \\ Hasil Penelitian \\ Uji Asumsi Klasik \\ Uji Multkolinieritas}

Uji Multikolinearitas bertujuan untuk menguji apakah model regresi ditemukan adanya korelasi antar variabel independen.

\section{Tabel 1}

\section{Hasil Pengujian Multikolinieritas}

Coefficients $^{\mathrm{a}}$

\begin{tabular}{|c|c|c|c|c|c|c|c|}
\hline \multirow[b]{2}{*}{ Model } & \multicolumn{2}{|c|}{$\begin{array}{c}\text { Unstandardized } \\
\text { Coefficients }\end{array}$} & \multirow{2}{*}{$\begin{array}{c}\begin{array}{c}\text { Standardized } \\
\text { Coefficients }\end{array} \\
\text { Beta }\end{array}$} & \multirow[b]{2}{*}{$\mathrm{t}$} & \multirow[b]{2}{*}{ Sig. } & \multicolumn{2}{|c|}{ Collinearity Statistics } \\
\hline & $\mathrm{B}$ & Std. Error & & & & Tolerance & VIF \\
\hline 1 (Constant) & 42.818 & 2.275 & & 18.818 & .000 & & \\
\hline Pengaruh_Kepercayaan & -.168 & .076 & -.142 & -2.215 & .028 & .993 & 1.008 \\
\hline Harga & -.121 & .108 & -.072 & -1.125 & .262 & .993 & 1.008 \\
\hline
\end{tabular}

a. Dependent Variable: Keputusan_Pembelian_Online

Sumber: Data primer yang telah diolah, 2019

Dari hasil tabel. 1. diatas dapat diketahui nilai inflaction factor (VIF) kedua variabel, yaitu pengaruh kepercayaan sebesar 1,008 dan harga sebesar 1,008 kurang dari 10, dan nilai tolerance kedua variabel lebih besar dari 0,10 sehingga dapat disimpulkan bahwa kedua variabel independen tidak terjadi persoalan multikolinieritas.

\section{Uji Heteroskedastisitas}

Pada pengujian heteroskedastisitas penelitian ini mengunakan metode Glejser dengan cara menyusun regresi antara nilai absolut residual dengan variabel bebas. Adapun hasil pengujian dapat kita lihat pada tabel 2 berikut:

Tabel 2

\section{Hasil Pengujian Heteroskedastisitas}

Coefficients $^{\mathrm{a}}$

\begin{tabular}{|c|c|c|c|c|c|}
\hline \multirow[b]{2}{*}{ Model } & \multicolumn{2}{|c|}{ Unstandardized Coefficients } & \multirow{2}{*}{$\begin{array}{c}\begin{array}{c}\text { Standardized } \\
\text { Coefficients }\end{array} \\
\text { Beta }\end{array}$} & \multirow[b]{2}{*}{$\mathrm{t}$} & \multirow[b]{2}{*}{ Sig. } \\
\hline & $\mathrm{B}$ & Std. Error & & & \\
\hline 1 (Constant) & 2.902 & 1.351 & & 2.147 & .033 \\
\hline Pengaruh_Kepercayaan (X1) & .007 & .045 & .010 & .147 & .883 \\
\hline Harga (X2) & .016 & .064 & .017 & .254 & .800 \\
\hline
\end{tabular}

a. Dependent Variable: Abs_RES

Sumber: Data primer yang telah diolah, 2019

Berdasarkan output diatas diketahui nilai signifikansi variabel pengaruh kepercayaan sebesar 0,883 lebih besar dari 0,05 , artinya tidak terjadi heteroskedastisitas pada variabel persepsi kualitas. 
Sementara itu, diketahui nilai signifikansi varibel harga yakni 0,800 lebih besar dari 0,05 , artinya tidak terjadi heteroskedastisitas pada variabel harga.

\section{Uji Auto Korelasi}

Pada pengujian auto korelasi penelitian ini mengunakan metode durbin Watson. Metode Durbin Watson adalah sebuah test yang digunakan untuk mendeteksi terjadinya autokorelasi pada nilai residual (prediction errors) dari sebuah analisis regresi. Yang dimaksud dengan Autokorelasi adalah "hubungan antara nilai-nilai yang dipisahkan satu sama lain dengan jeda waktu tertentu". Adapun hasil pengujian dapat kita lihat pada tabel 3 berikut:

Tabel 3

\section{Hasil Pengujian Auto Korelasi} Model Summary ${ }^{\mathrm{b}}$

\begin{tabular}{|c|c|c|c|c|c|c|c|c|c|c|}
\hline \multirow[b]{2}{*}{ Model } & \multirow[b]{2}{*}{$\mathrm{R}$} & \multirow[b]{2}{*}{$\begin{array}{c}\mathrm{R} \\
\text { Square }\end{array}$} & \multirow[b]{2}{*}{$\begin{array}{l}\text { Adjusted R } \\
\text { Square }\end{array}$} & \multirow[b]{2}{*}{$\begin{array}{l}\text { Std. Error of the } \\
\text { Estimate }\end{array}$} & \multicolumn{5}{|c|}{ Change Statistics } & \multirow{2}{*}{$\begin{array}{l}\text { Durbin- } \\
\text { Watson }\end{array}$} \\
\hline & & & & & $\begin{array}{l}\text { R Square } \\
\text { Change }\end{array}$ & $\begin{array}{c}\mathrm{F} \\
\text { Change }\end{array}$ & df1 & $\mathrm{df} 2$ & $\begin{array}{c}\text { Sig. F } \\
\text { Change }\end{array}$ & \\
\hline 1 & $165^{\mathrm{a}}$ & .027 & .019 & 4.123 & .027 & 3.328 & 2 & 237 & .038 & 1.908 \\
\hline
\end{tabular}

a. Predictors: (Constant), Harga (X2), Pengaruh_Kepercayaan (X1)

b. Dependent Variable: Keputusan_Pembelian_Online (Y)

Sumber: Data primer yang telah diolah, 2019

Cara menentukan atau kriteria pengujian autokorelasi berdasarkan nilai DW tidak akan terlepas dengan tabel Durbin Watson. Tabel tersebut menjadi alat pembanding terhadap nilai Durbin Watson hitung. Kriteria pengujian autokorelasi berdasarkan nilai DW adalah sebagai berikut:

Deteksi Autokorelasi Positif:

Maka nilai $\mathrm{T}=240, \mathrm{k}=3$. Selanjutnya pada tabel di atas cari nilai $\mathrm{dL}$ dan $\mathrm{dU}$ pada $\mathrm{T}=240 \mathrm{dan} \mathrm{k}=3$, yaitu nilai $\mathrm{dL}=1,77171$ dan $\mathrm{dU}=1,80530$. Pada contoh di atas, nilai $\mathrm{d}=1,908$, maka kita hitung terlebih dahulu nilai $(4-\mathrm{d})=2,092$.

\section{Deteksi Autokorelasi Positif:}

Jika $1,908<1,77171$ maka terdapat autokorelasi positif $\rightarrow$ Salah

Jika $1,908>1,80530$ maka tidak terdapat autokorelasi positif $\rightarrow$ Benar

Jika $1,77171<1,908<1,80530$ maka pengujian tidak meyakinkan atau tidak dapat disimpulkan $\rightarrow$ Salah

Maksud di atas adalah, DW: 1,908 > DU: 1,80530, maka tidak terdapat autokorelasi positif.

\section{Deteksi Autokorelasi Negatif:}

Jika 2,092 $<1,77171$ maka terdapat autokorelasi negatif $\rightarrow$ Salah

Jika 2,092 $>1,80530$ maka tidak terdapat autokorelasi negatif $\rightarrow$ Benar

Jika $1,77171<2,092<1,80530$ maka pengujian tidak meyakinkan atau tidak dapat disimpulkan $\rightarrow$ Salah

Maksud di atas adalah, 4-DW: 1,908 yaitu 2,092 > DU: 1,80530, maka tidak terdapat autokorelasi negatif.

Maka dapat disimpulkan: pada analisis regresi tidak terdapat autokorelasi positif dan tidak terdapat autokorelasi negatif sehingga bisa disimpulkan sama sekali tidak terdapat autokorelasi.

\section{Uji Linieritas}

Secara umum uji linieritas bertujuan untuk mengetahui apakah dua variable yang mempunyai hubungan linier secara signifikan atau tidak. Korelasi yang baik seharusnya terdapat hubungan yang linear antara variable independent $(\mathrm{X})$ dengan variable dependent $(\mathrm{Y})$.

Dasar pengambilan keputusan dalam Uji Linieritas

1. Membandingkan Nilai Signifikansi (Sig.) dengan 0,05

a. Jika nilai Deviation from Linierity Sig. $>0,05$, maka ada hubungan yang linear secara signifikan antara variable independen dengan varibel dependent.

b. Jika nilai Deviation from Linierity Sig. $<0,05$, maka tidak ada hubungan yang linear secara signifikan antara variable independen dengan varibel dependent. 
2. Membandingkan nilai $F$ hitung dengan $F$ table

a. Jika nilai $\mathrm{F}$ hitung $<\mathrm{F}$ tabel, maka ada hubungan yang linear secara signifikan antara variable independen dengan varibel dependent.

b. Jika nilai $\mathrm{F}$ hitung $>\mathrm{F}$ tabel, maka tidak ada hubungan yang linear secara signifikan antara variable independen dengan varibel dependent.

Tabel 4.

Hasil Pengujian Linieritas ANOVA Table

\begin{tabular}{|c|c|c|c|c|c|c|c|}
\hline & & & $\begin{array}{l}\text { Sum of } \\
\text { Squares }\end{array}$ & df & $\begin{array}{l}\text { Mean } \\
\text { Square }\end{array}$ & $\mathrm{F}$ & Sig. \\
\hline \multirow{5}{*}{$\begin{array}{l}\text { Keputusan_Pembelian_Onl } \\
\text { ine (Y)* } \\
\text { Pengaruh_Kepercayaan } \\
\text { (X1) }\end{array}$} & Between & (Combined) & 317.892 & 17 & 18.700 & 1.086 & .369 \\
\hline & Groups & Linearity & 91.614 & 1 & 91.614 & 5.319 & .022 \\
\hline & & Deviation from Linearity & 226.278 & 16 & 14.142 & .821 & .661 \\
\hline & \multicolumn{2}{|c|}{ Within Groups } & 3824.041 & 222 & 17.225 & & \\
\hline & \multicolumn{2}{|l|}{ Total } & 4141.933 & 239 & & & \\
\hline
\end{tabular}

Sumber: Data primer yang telah diolah, 2019

Tabel 5.

Hasil Pengujian Linieritas

Variabel Harga dengan Variabel Keputusan Pembelian Online

ANOVA Table

\begin{tabular}{|c|c|c|c|c|c|c|c|}
\hline & & & $\begin{array}{l}\text { Sum of } \\
\text { Squares }\end{array}$ & df & $\begin{array}{l}\text { Mean } \\
\text { Square }\end{array}$ & $\mathrm{F}$ & Sig. \\
\hline \multirow{5}{*}{$\begin{array}{l}\text { Keputusan_Pembelian_Onl } \\
\text { ine }(\mathrm{Y}) * \text { Harga }(\mathrm{X} 2)\end{array}$} & \multirow{3}{*}{ Between Groups } & (Combined) & 134.508 & 12 & 11.209 & .635 & .811 \\
\hline & & Linearity & 29.703 & 1 & 29.703 & 1.683 & .196 \\
\hline & & $\begin{array}{l}\text { Deviation from } \\
\text { Linearity }\end{array}$ & 104.805 & 11 & 9.528 & .540 & .875 \\
\hline & \multicolumn{2}{|l|}{ Within Groups } & 4007.425 & 227 & 17.654 & & \\
\hline & \multicolumn{2}{|l|}{ Total } & 4141.933 & 239 & & & \\
\hline
\end{tabular}

Sumber: Data primer yang telah diolah, 2019

1. Berdasarkan Nilai Signifikansi (Sig.):

a. Variabel Pengaruh Kepercayaan (X1) dengan variabel Keputusan Pembelian Online (Y)

Dari output diatas, diperoleh nilai Deviation from Linearity Sig. adalah 0,661. Jadi nilai Deviation from Linearity Sig. 0,661 lebih besar dari 0,05. Maka dapat disimpulkan bahawa ada hubungan linear secara signifikan antara variabel pengaruh kepercayaan (X1) dengan variabel keputusan pembelian online (Y)

b. Variabel Harga (X2) dengan variabel Keputusan Pembelian Online (Y)

Dari output diatas, diperoleh nilai Deviation from Linearity Sig. adalah 0,875. Jadi nilai Deviation from Linearity Sig. 0,875 lebih besar dari 0,05. Maka dapat disimpulkan bahawa ada hubungan linear secara signifikan antara variabel pengaruh kepercayaan (X1) dengan variabel keputusan pembelian online (Y)

2. Berdasarkan Nilai F:

a. Variabel Pengaruh Kepercayaan (X1) dengan variabel Keputusan Pembelian Online (Y)

Dari output diatas, diperoleh nilai $\mathrm{F}$ hitung adalah $0,821<\mathrm{F}$ tabel 1,689. Karena nilai $\mathrm{F}$ hitung lebih kecil dari $\mathrm{F}$ tabel maka. Maka dapat disimpulkan bahawa ada hubungan linear secara signifikan antara variabel pengaruh kepercayaan (X1) dengan variabel keputusan pembelian online (Y)

b. Variabel Harga (X2) dengan variabel Keputusan Pembelian Online (Y)

Dari output diatas, diperoleh nilai $\mathrm{F}$ hitung adalah $0,540<\mathrm{F}$ tabel 1,689 . Karena nilai $\mathrm{F}$ hitung lebih kecil dari F table maka. Maka dapat disimpulkan bahawa ada hubungan linear secara signifikan antara variabel pengaruh kepercayaan (X1) dengan variabel keputusan pembelian online $(\mathrm{Y})$

Uji Regresi Linier Berganda 
Analisis regresi linier berganda adalah hubungan secara linear antara satu variabel independen (X) dengan variabel dependen (Y). Analisis ini untuk mengetahui arah hubungan antara variabel independen dengan variabel dependen apakah positif atau negatif dan untuk memprediksi nilai dari variabel dependen apabila nilai variabel independen mengalami kenaikan atau penurunan. Berdasarkan hasil dari analisis regresi linier berganda yang dihitung dalam program IBM SPSS (Statistical Product And Service Solution) Statistics 23, diperoleh hasil seperti tabel 6 berikut ini:

Tabel 6

Hasil Analisis Regresi Linier Berganda Coefficients $^{\mathrm{a}}$

\begin{tabular}{|c|c|c|c|c|c|}
\hline \multirow[b]{2}{*}{ Model } & \multicolumn{2}{|c|}{ Unstandardized Coefficients } & \multirow{2}{*}{$\frac{\text { Standardized Coefficients }}{\text { Beta }}$} & \multirow[b]{2}{*}{$\mathrm{t}$} & \multirow[b]{2}{*}{ Sig. } \\
\hline & $\mathrm{B}$ & Std. Error & & & \\
\hline 1 (Constant) & 42.818 & 2.275 & & 18.818 & .000 \\
\hline Pengaruh_Kepercayaan (X1) & -.168 & .076 & -.142 & -2.215 & .028 \\
\hline Harga (X2) & -.121 & .108 & -.072 & -1.125 & .262 \\
\hline
\end{tabular}

a. Dependent Variable: Keputusan_Pembelian_Online (Y)

Sumber: Data kuisioner yang telah diolah, 2019

Berdasarkan tabel diatas dapat diketahui persamaan regresi yang terbentuk adalah:

$$
\mathrm{Y}=\mathbf{4 2 , 8 1 8}-\mathbf{0 , 1 6 8 X _ { 1 } - 0 , 1 2 1 X _ { 2 }}
$$

Dari persamaan tersebut dapat dijelaskan bahwa:

1. Ini berarti semua variabel bebas memiliki nilai nol (0) maka nilai variabel dependent sebesar 42,818 .

2. Nilai koefiesien pengaruh kepercayaan $\left(\mathrm{X}_{1}\right)$ sebesar $-0,168$ dan bertanda negatif, ini menunjukkan bahwa variabel kepercayaan mempunyai hubungan yang berlawanan arah. Hal ini mengandung arti bahwa setiap kenaikan pengaruh kepercayaan satu satuan maka variabel keputusan pembelian online akan turun sebesar 0,168 dengan asumsi bahwa variabel bebas yang lain dari model regresi adalah tetap.

3. Nilai koefiesien harga $\left(\mathrm{X}_{2}\right)$ sebesar $-0,121$ dan bertanda negatif, ini menunjukkan bahwa variabel kepercayaan mempunyai hubungan yang berlawanan arah. Hal ini mengandung arti bahwa setiap kenaikan harga satu satuan maka variabel keputusan pembelian online akan turun sebesar 0,121 dengan asumsi bahwa variabel bebas yang lain dari model regresi adalah tetap.

\section{Pengujian Hipotesis}

\section{Uji Simultan (uji F)}

Untuk menguji pengaruh variabel bebas secara bersama-sama diuji dengan menggunakan uji $\mathrm{F}$. Hasil perhitungan regresi diperoleh sebagai berikut:

\section{Tabel 7}

\section{Hasil Uji F Secara Simultan} ANOVA $^{\mathrm{a}}$

\begin{tabular}{|ll|r|r|r|r|r|}
\hline Model & & Sum of Squares & Df & Mean Square & F & Sig. \\
\hline 1 & Regression & 113.138 & 2 & 56.569 & 3.328 & $.038^{\mathrm{b}}$ \\
& Residual & 4028.795 & 237 & 16.999 & & \\
& Total & 4141.933 & 239 & & & \\
\hline
\end{tabular}

a. Dependent Variable: Keputusan_Pembelian_Online (Y)

b. Predictors: (Constant), Harga (X̄2), Pengaruh_Kepercayaan (X1)

Sumber: Data kuisioner yang telah diolah, 2019

1) Pengujian pengaruh variabel bebas secara bersama-sama terhadap variabel terikatnya dilakukan dengan menggunakan uji $\mathrm{F}$. Hasil perhitungan statistik menunjukkan nilai $\mathrm{F}$ hitung $=3.328$, sedangkan $\mathrm{F}$ tabel $=3,88$ maka diperoleh nilai $\mathrm{F}$ hitung $3.328<3,88$. Maka $\mathrm{H}_{0}$ diterima dan $\mathrm{H}_{\mathrm{a}}$ ditolak. Hal ini berarti bahwa tidak ada pengaruh kepercayaan dan harga secara bersama terhadap terhadap keputusan pembelian online melalui media social Instagram pada Mahasiswa Program Studi S1 STIE Rahmaniyah Sekayu.

\section{Uji Parsial (uji t)}

Berdasarkan perhitungan SPSS, maka dapat diketahui hasil analisis koefisien regresi seperti tabel 7 berikut: 


\section{Tabel 7}

Hasil Uji t

Coefficients $^{\mathrm{a}}$

\begin{tabular}{|l|r|r|r|r|r|}
\hline \multirow{2}{*}{ Model } & \multicolumn{2}{|c|}{$\begin{array}{c}\text { Unstandardized } \\
\text { Coefficients }\end{array}$} & \multicolumn{2}{c|}{$\begin{array}{c}\text { Standardized } \\
\text { Coefficients }\end{array}$} & \\
\cline { 2 - 5 } & \multicolumn{1}{|c|}{ B } & Std. Error & Beta & \multicolumn{1}{c|}{ Sig. } \\
\hline 1 (Constant) & 42.818 & 2.275 & & 18.818 & .000 \\
Pengaruh_Kepercayaan (X1) & -.168 & .076 & -.142 & -2.215 & .028 \\
Harga (X2) & -.121 & .108 & -.072 & -1.125 & .262 \\
\hline
\end{tabular}

a. Dependent Variable: Keputusan_Pembelian_Online (Y)

Sumber: Data kuisioner yang telah diolah, 2019

Sampel yang digunakan sebanyak 240 orang, sehingga pengujian menggunakan uji t dengan df $=\mathrm{n}-2$ atau $240-2=238$ dan tingkat signifikasi $(\alpha)=5 \%$. Maka diperoleh $\mathrm{T}_{\text {tabel }}$ sebesar 1,651 , dengan pengambilan keputusan:

1. Pengujian koefisien regresi variabel pengaruh kepercayaan $\left(\mathrm{H}_{1}\right)$

Perumusan hipotesis:

a. Ho diterima dan Ha di tolak apabila, sig $\mathrm{t}>\alpha 0,05$ atau $\mathrm{t}$ hitungan $\leq \mathrm{t}$ tabel, artinya tidak ada pengaruh kepercayaan secara parsial terhadap keputusan keputusan pembelian online melalui media social Instagram pada Mahasiswa Program Studi S1 STIE Rahmaniyah Sekayu.

b. Ho ditolak dan Ha diterima apabila sig $\mathrm{t}<\alpha(0,05)$ atau $\mathrm{t}$ hitungan $>\mathrm{t}$ tabel, artinya ada pengaruh kepercayaan secara parsial terhadap keputusan keputusan pembelian online melalui media social Instagram pada Mahasiswa Program Studi S1 STIE Rahmaniyah Sekayu.

Dari tabel 7 terlihat bahwa hasil pengujian hipotesis pengaruh kepercayaan menunjukkan nilai t hitung $<$ t tabel $(-2,215<1,651)$ dan nilai signifikansi (Sig.) $0,028<0,05$. Maka dapat disimpulkan $\mathrm{H}_{0}$ ditolak. Artinya secara parsial tidak ada pengaruh signifikan antara persepsi kualitas dengan keputusan konsumen. Jadi dalam penelitian ini dapat disimpulkan bahwa secara parsial pengaruh kepercayaan tidak berpengaruh terhadap keputusan keputusan pembelian online melalui media social Instagram pada Mahasiswa Program Studi S1 STIE Rahmaniyah Sekayu.

2. Pengujian koefisien regresi variabel harga $\left(\mathrm{H}_{2}\right)$

Perumusan hipotesis:

a. Ha diterima dan Ho di tolak apabila, sig $\mathrm{t}>\alpha 0,05$ atau $\mathrm{t}$ hitungan $<\mathrm{t}$ tabel, artinya tidak ada pengaruh harga secara parsial terhadap keputusan keputusan pembelian online melalui media social Instagram pada Mahasiswa Program Studi S1 STIE Rahmaniyah Sekayu.

b. Ho ditolak dan Ha diterima apabila sig $\mathrm{t}<\alpha(0,05)$ atau $\mathrm{t}$ hitungan $>\mathrm{t}$ tabel, artinya ada pengaruh harga secara parsial terhadap keputusan keputusan pembelian online melalui media social Instagram pada Mahasiswa Program Studi S1 STIE Rahmaniyah Sekayu.

Dari tabel 7 terlihat bahwa hasil pengujian hipotesis harga menunjukkan nilai $\mathrm{t}$ hitung $<\mathrm{t}$ tabel $(-$ $1,125<1,651$ ) dan nilai signifikansi (Sig.) $0,062>0,05$. Maka dapat disimpulkan $\mathrm{H}_{0}$ diterima dan $\mathrm{H}_{a}$ diterima. Artinya secara parsial tidak ada pengaruh signifikan antara harga dengan keputusan pembelian online. Jadi dalam penelitian ini dapat disimpulkan bahwa secara parsial tidak ada berpengaruh harga secara parsial terhadap keputusan keputusan pembelian online melalui media social Instagram pada Mahasiswa Program Studi S1 STIE Rahmaniyah Sekayu.

\section{Uji Korelasi}

Analisa korelasi sederhana (bivariate corelation) digunakan untuk mengetahui keeratan hubungan dua variabel dan mengetahui arah hubungan yang terjadi. Koefisien korelasi sederhana menunjukkan seberapa besar hubungan yang terjadi antara dua variabel. Menurut Sugiyono (2013: 115), menyatakan pedoman untuk memberikan interprestasi koefisien korelasi adalah :

a. Jika korelasi 0,0 sampai 0,199 hubungannya sangat rendah.

b. Jika korelasi 0,200 sampai 0,339 hubungannya rendah.

c. Jika korelasi 0,400 sampai 0,599 hubungannya sedang.

d. Jika korelasi 0,600 sampai 0,799 hubungannya kuat.

e. Jika korelasi 0,800 sampai 1,000 sangat kuat. 


\section{Tabel 8}

Hasil Analisis Korelasi Sederhana

Model Summary ${ }^{b}$

\begin{tabular}{|l|r|r|r|r|}
\hline Model & $\mathrm{R}$ & \multicolumn{1}{|c|}{ R Square } & Adjusted R Square & \multicolumn{2}{|c|}{ Std. Error of the Estimate } \\
\hline 1 & $.165^{\mathrm{a}}$ & .027 & .019 & \\
\hline
\end{tabular}

a. Predictors: (Constant), Harga (X2), Pengaruh_Kepercayaan (X1)

Sumber: Data kuisioner yang telah diolah, 2019

Dari tabel 8 diatas diketahui nilai korelasi (R) sebesar 0,165 , hal ini menunjukkan hubungan yang sangat rendah karena berada di kisaran 0,000 sampai 0,199

\section{Uji Koefisien Determinasi (R2)}

Koefisien determinasi merupakan besaran yang menunjukkan besarnya variasi dependen yang dapat dijelaskan oleh variabel independennya. Nilai koefisien determinasi ditentukan dengan nilai adjusted $R$ square sebagaimana dapat dilihat pada tabel 8:

Tabel 8

Koefisien Determinasi Model Summary ${ }^{b}$

\begin{tabular}{|l|c|r|r|r|}
\hline Model & $\mathrm{R}$ & \multicolumn{1}{|c|}{ R Square } & Adjusted R Square & Std. Error of the Estimate \\
\hline 1 & $.165^{\mathrm{a}}$ & .027 & .019 & 4.123 \\
\hline
\end{tabular}

a. Predictors: (Constant), Harga (X2), Pengaruh_Kepercayaan (X1)

Sumber: Data kuisioner yang telah diolah, 2019

Hasil perhitungan regresi dapat diketahui bahwa koefisien determinasi (square R2) yang diperoleh sebesar 0,027 . Hal ini berarti $2,7 \%$ variasi variabel keputusan pembelian online dapat dijelaskan oleh variabel pengaruh kepercayaan dan harga sedangkan sisanya sebesar 97,3\% diterangkan oleh variabel lain yang tidak dianalisis atau dibahas dalam penelitian ini.

\section{Pembahasan}

Berdasarkan hasil pengujian statistik dapat terlihat dengan jelas bahwa secara parsial (individu) variabel pengaruh kepercayaan dan variabel tidak berpengaruh terhadap variabel terikat yakni keputusan pembelian online.

\section{Pengaruh Kepercayaan terhadap Keputusan pembelian Online}

Hasil pengujian hipotesis pengaruh kepercayaan menunjukkan nilai $t$ hitung $<\mathrm{t}$ tabel $(-2,215$ $<1,651$ ) dan nilai signifikansi (Sig.) $0,028>0,05$. Artinya secara parsial tidak ada pengaruh signifikan antara persepsi kualitas dengan keputusan konsumen. Jadi dalam penelitian ini dapat disimpulkan bahwa secara parsial pengaruh kepercayaan tidak berpengaruh terhadap keputusan pembelian online melalui media social Instagram pada Mahasiswa Program Studi S1 STIE Rahmaniyah Sekayu.

\section{Pengaruh Harga terhadap Keputusan pembelian Online}

Hasil pengujian hipotesis harga menunjukkan nilai t hitung $<\mathrm{t}$ tabel $(-1,125<1,651)$ dan nilai signifikansi (Sig.) 0,062 $>0,05$. Maka dapat disimpulkan $\mathrm{H}_{0}$ diterima dan $\mathrm{H}_{\mathrm{a}}$ diterima. Artinya secara parsial tidak ada pengaruh signifikan antara harga dengan keputusan pembelian online. Jadi dalam penelitian ini dapat disimpulkan bahwa secara parsial ada berpengaruh signifikan harga secara parsial terhadap keputusan keputusan pembelian online melalui media social Instagram pada Mahasiswa Program Studi S1 STIE Rahmaniyah Sekayu.

\section{Pengaruh Pegaruh Kepercayaan dan Harga terhadap Keputusan Pembelian}

Pengujian pengaruh variabel bebas secara bersama-sama terhadap variabel terikatnya dilakukan dengan menggunakan uji F. Hasil perhitungan statistik menunjukkan nilai $\mathrm{F}$ hitung $=3.328$, sedangkan $\mathrm{F}$ tabel $=3,88$ maka diperoleh nilai $\mathrm{F}$ hitung $3.328<3.88$. Maka $\mathrm{H}_{0}$ diterima dan $\mathrm{H}_{\mathrm{a}}$ ditolak. Hal ini berarti bahwa tidak ada pengaruh kepercayaan dan harga secara bersama terhadap terhadap keputusan pembelian online melalui media social Instagram pada Mahasiswa Program Studi S1 STIE Rahmaniyah Sekayu.

\section{Kesimpulan}


Dari pembahasan yang telah diuraikan diatas, maka dapat ditarik kesimpulan:

1. Hasil pengujian hipotesis pengaruh kepercayaan menunjukkan nilai $\mathrm{t}$ hitung $<\mathrm{t}$ tabel $(-2,215<$ $1,651)$ dan nilai signifikansi (Sig.) $0,028>0,05$. Artinya secara parsial tidak ada pengaruh signifikan antara persepsi kualitas dengan keputusan konsumen. Jadi dalam penelitian ini dapat disimpulkan bahwa secara parsial pengaruh kepercayaan sangat berpengaruh terhadap keputusan pembelian online melalui media social Instagram pada Mahasiswa Program Studi S1 STIE Rahmaniyah Sekayu.

2. Hasil pengujian hipotesis harga menunjukkan nilai $\mathrm{t}$ hitung $<\mathrm{t}$ tabel $(-1,125<1,651)$ dan nilai signifikansi (Sig.) 0,062 >0,05. Maka dapat disimpulkan $\mathrm{H}_{0}$ diterima dan $\mathrm{H}_{\mathrm{a}}$ ditolak. Artinya secara parsial tidak ada pengaruh signifikan antara harga dengan keputusan pembelian online. Jadi dalam penelitian ini dapat disimpulkan bahwa secara parsial ada berpengaruh harga secara parsial terhadap keputusan pembelian online melalui media social Instagram pada Mahasiswa Program Studi S1 STIE Rahmaniyah Sekayu.

3. Pengujian pengaruh variabel bebas secara bersama-sama terhadap variabel terikatnya dilakukan dengan menggunakan uji $\mathrm{F}$. Hasil perhitungan statistik menunjukkan nilai $\mathrm{F}$ hitung $=3.328$, sedangkan $\mathrm{F}$ tabel $=3,88$ maka diperoleh nilai $\mathrm{F}$ hitung $3.328<3,88$. Maka $\mathrm{H}_{0}$ diterima dan $\mathrm{H}_{\mathrm{a}}$ ditolak. Hal ini berarti bahwa tidak ada pengaruh

kepercayaan dan harga secara bersama terhadap terhadap keputusan pembelian online melalui media social Instagram pada Mahasiswa Program Studi S1 STIE Rahmaniyah Sekayu.

\section{DAFTAR PUSTAKA}

Abdurahman,. Muhidin., dan somantri. 2011. Dasar-dasar metode statistika untuk penelitian. Bandung: Pustaka Setia.

Buchari, Alma. 2011. Manajemen Pemasaran dan Pemasaran Jasa, Cetakan. Kesembelian. Bandung: Alfabeth.

Daryanto. 2013. Sari Kuliah Manajemen Pemasaran. Cetakan II, Januari 2013. Bandung: PT. Sarana Tutorial Nurani Sejahtera.

Fasochah dan Hartono. 2013. Analisis Pengaruh Kepercayaan dan Kualitas Layanan Terhadap Loyalitas Pelanggan dengan Kepuasan Konsumen Sebagai Variabel Mediasi (Studi Pada RS Darul Istiqomah Kaliwungu Kendal), Jurnal Ekonomi Manajemen Akuntansi, No. 34, Th. XX, 1-22.

Fransiska, Kony. 2018. Analisa Pengaruh Harga, Desain dan Celebrity Endorser Terhadap Keputusan Pembelian Produk Pakaian (Studi Kasus pada Konsumen R.A. Jeans di Media Sosial Instagram Skripsi. Program Studi Manajemen Fakultas Ekonomi. Yogyakarta, Universitas Sanata Dharma

Ghazali, Miliza. 2016. Buat Duit Dengan Facebook dan Instagram: Panduan Menjana Pendapatan dengan Facebook dan Instagram. Malaysia: Publishing House.

Hasanah, N. Syah, 2017. Analisis Faktor-faktor yang Mempengaruhi Keputusan Pembelian Melalui Online Shop di Kota Medan. Thesis, Program Studi Ekonomi Islam. Medan, Pascasarjana Universitas Islam Negeri Sumatera Utara.

Kotler, Philip dan Kevin Lane Keller, 2016. Marketing Managemen, 15th Edition, Pearson Education, Inc..

Kotler Philip, Amstrong Gary. 2012. Prinsip-Prinsip Pemasaran, Edisi ke-12, Jilid 1. Terjemahan Bob Sabran Jakarta: Erlangga.

Pusposari, Anis. 2017. Pengaruh Kualitas Layanan, Kepercayaan, dan Harga Terhadap Keputusan Pembelian Online Produk Busana Melalui Media Sosial Instagram di Kalangan Mahasiswa Fakultas Ekonomi dan Bisnis Islam IAIN Surakarta.Jurusan Manajemen Binis Syariah Fakultas Ekonomi dan Bisnis Islam. Solo, IAIN Surakarta.

Sanusi, Anwar. 2011. MetodologiPenelitianBisnis. CetakanKetiga. Penerbit

SalembaEmpat. Jakarta

Sugiyono. 2012. Metode Penelitian Kuantitatif Kualitatif dan R\&D. Bandung: Alfabeta. 
Sukwadi, R., Inderawati, M.W., Indah, M.Y., 2016. Perilaku Konsumen dalam Pemilihan Online Shop Instagram. Jurnal Metris, 17. 123 - 132

Suny. 2017. Pengaruh Kepercayaan, Kemudahan dan Kualitas Informasi Penjualan Terhadap Keputusan Pembelian Sara Online oleh Mahasiswa Politeknik Negeri Batam. Program Studi Akuntansi Manajerial Jurusan Manajemen Bisnis. Batam, Politeknik Negeri Batam.

Widyawati, Nurul. 2008. Pengaruh Kepercayaan dan Komitmen Serta Bauran Pemasaran Jasa Terhadap Loyalitas Konsumen di Hotel Zakiyah Medan. Jurnal Ekuitas, Vol. 12, No. 1, 74-96.

Wijaya, Petra dan Christina Teguh. 2012. Faktor-Faktor yang Mempengaruhi Minat Beli di Online Shop Specialis Guess, JRMB, Vol. 7, No. 2, 147-160. 